\section{ANDAMAN COAST MUSLIM SOCIAL CIRCLES AND FRIENDSHIP NETWORKS}

\author{
Wanni W. Anderson ${ }^{1}$
}

\begin{abstract}
On Nipa Island (a pseudonym), in a Thai Muslim community on the Andaman coast, childhood is a happy period as children are pampered and loved and spend long, happy hours in the company of their homevillage friends. From these sustained social interactions develop long-lasting friendships that function importantly later on in adult life. Kloe-ship, another form of friendship is unique to Southern Thailand. Comparative human development, discourse analysis, kinesic analysis, and multiplexity of social networks form the theoretical approaches to the analysis of the ethnographic data.
\end{abstract}

\section{Nipa Island, Krabi, 1983}

I had been living on Nipa Island for half a year as a member of Harvard University's cross-cultural study project "Adolescence in a Changing World." As is customary in anthropological field research, I roamed around the village observing, chatting, interviewing, and participating in the activities that went on, trying to understand what it was like to come of age in this Thai Muslim community, what Muslim lifeways and viewpoints were, what their happy moments were, and what constituted their life choices and aspirations.

\footnotetext{
${ }^{1}$ Professor, Department of Anthropology Brown University, Providence, RI, U.S.A
}

One morning, Visidh Mayacheo, my research assistant, informed me that Dara (a pseudonym), a female adolescent in our study group, had eloped the previous night. I had by then developed a relaxed relationship with Dara and her big sister, also a member of our adolescent study group, and had frequently visited with their parents at their house in the middle of the hamlet. I hadn't heard a word about the elopement. Neither had I met the young man Dara had eloped with.

From Visidh, I learned that Dara's close friends had been secretly and closely involved with the organization of the elopement. At that point, Dara's despondent parents had no inkling of their daughter's whereabouts. Neither had Dara's big sister. I had earlier participated in a wedding on the island where the couple was happily married with the approval and best wishes of the families. Dara's elopement was an anomaly. It was kept under wraps, a hushhush village drama that did not invite inquiry from individuals outside the family. The event put a new perspective on my assumptions about friendship as it was culturally constructed and acted out in real life on the island.

\section{Ethnographic setting}

Demographically, Muslims constitute $4.6 \%$ of the total population of Thailand, or 2.8 million of the 60.6 million people that make up Thailand's total population, as enumerated in the latest 2000 census, based on self-identification by religious faith. Next to the Sino-Thai, the Muslims are the second largest ethnic group in Thailand. The largest concentration of Muslims, i.e., $78.4 \%$, live in provinces in the south of Thailand. While the majority of Muslims on the southeastern coast around Pattani see themselves as Malay 
Muslims, those on the southwestern coast along the Andaman Sea identify themselves as Thai Muslims, that is, Thai of Islamic faith. In Krabi, Thai Muslims constitute $40.7 \%$ of the population, making Krabi the province with the second largest number of Muslim residents on the Andaman coast.

Thai Muslims in Krabi have long-standing historical, political, economic, and social relationships with Southern Thai speakers of Phuket and Nakhon Si Thammarat. Since language is a significant cultural marker and signifier of group identity, it is important to note that the lingua franca of the Thai Muslim groups on the Andaman coast, including Nipa Island, is phasa tai ${ }^{2}$, the Southern Thai dialect. An oral history of the settlement of the Thai Muslims on Nipa Island collected from an old family tells of a Buddhist Thai Thalang (Phuket) husband who had converted to Islam and who fled with his family after the ThalangBurma war at the beginning of King Rama I's reign, settling on the island over 200 years ago. The island is now a fishing and rice-farming community, and the youngest generation is the 7th generation living on the island. Economically, while men earn cash income as hired hands on oceanfishing trawlers (uan dam), having, until recently, operated privately-owned pushnet fishing boats (uan run), or run commuter taxiboats between the island and mainland Krabi, women work as subsistence rice farmers and run small businesses like convenience stores, coffee shops, and snack shops on the island.

\footnotetext{
${ }^{2}$ The spelling of Thai words, except personal names, in this paper is based on the Thai romanization program 1.25 developed by Aroonmanakun (2004). The program is based on the Thai Royal Institute romanization system.
}

\section{Growing up on the island}

On Nipa Island, children are much cherished and valued. Islamic religious precepts articulate strong support for motherhood, extolling a family with children as having been blessed by Allah. As observed around the hamlet during my 1982-1983 field season, small children were never left by themselves. They were constantly under the watchful eye of adults and older siblings. A common sight around the hamlet was a toddler being carried around on the hip of a big sister walking along a foot trail, the big sister sometimes also toting a grocery item in her other hand. Just as frequently witnessed was the scene of women acting as substitute mothers, feeding other women's children, playing with them, and comforting them when they fell down or suffered other mishaps, as well as scolding them when they misbehaved.

A parenting scene observed in a popular snack shop for women provides a contextual instance of what I call "communal babysitting." The shop, sitting in the middle of the hamlet, was a cool, open stall by a foot trail, run by four unmarried sisters. Selling coffee and snacks and frequented mostly by women, it had become a social gathering place for women living in the vicinity. A number of mothers arrived with an infant on their hip or a toddler in tow. I noticed that as soon as the mother sat down, the infant would be passed on to other women who would coo to them, bounce them, and keep them happy so that the mother could enjoy her snack and socialize. The children were all taught to call older women by respectful kinship terms: cha 'older sister' or $n e$ 'grandmother,' even when they were not related. 


\section{Children's social world}

Though without many modern amenities and expensive purchased toys, Nipa Island children grew up in a world that was happy and secure. The setting of the hamlet on an island meant that their childhood friends were either relatives or friends from nearby houses. Once in school, they would meet new friends from houses further away but still from the same hamlet. There at school, in the classroom and in the playground, they were brought into frequent interactions.

The social world of Nipa Island children was free and spontaneous during their childhood years (Anderson 1988). The school playground before classes in the morning and during lunch recess was always a lively social scene with students playing one game or another. In one corner, a group of second graders might be playing Shrimp Fishing, the Nipa Island version of Fox and Geese, with players taking on the roles of a shrimp fisherman, mother shrimp, and baby shrimps. Under another school building raised on concrete posts six feet off the ground, players in a fourth-grade group were running from post to post in another role-playing game, Monkey Steals the Post. To one side of the schoolyard, a group of girls played Jump Over the Rubberbands with rubberbands strung as a rope for jumping over increasing heights in different positions. And on the concrete pavement in front of the classroom, a group of girls would be playing Jacks with pebbles and a marble. I noticed from multiple play observations that one girl always had with her a small woven panan 'pandanus' palm basket that her weaver grandmother had lovingly woven for her as a pebble container. The basket was a miniature of the woven pandanus palm baskets that
Nipa Island women used for collecting and carrying rice from the paddies. In active interaction with their living environment and ludic creativity, the play equipment was all home-made: discarded items, pebbles, seeds, and palm stems collected from around the hamlet by the children themselves.

Before the recent introduction of the hijab school uniform a few years ago, boys and girls played together during their preschool years through the sixth grade, the last year of their elementary education on the island. It was not until around the sixth grade that some girls, reaching menarche, began to withdraw from these mixed-age and both-sex playgroups. Except during the physical education hour, all social and play interactions were initiated and organized by the children themselves. Besides playing, girls frequently visited each other at home, to chat or to cook snacks that they enjoyed making and sharing with each other. Often I noticed that, if a young girl happened to be working on an assigned task at the moment, the visiting girl friend would generously lend her a helping hand. Boys, more free-spirited and allowed greater freedom of movement, roamed around, exploring different parts of the island. This exploration acted as informal training about their local surroundings. From the estuary they would catch whatever fish they could. Often during the hours of high tide, they would join forces to try to trap crabs, an activity that was both play and work because the trapped crabs would be brought home for the family dinner. From these activities, boys played and practiced rudimentary fishing and crabbing skills. And from these shared childhood experiences and interactional contexts, intra-village friendships were forged and nourished. 
As Nipa Island children progressed from childhood to adolescence, their social fields, which had previously been restricted to the social scenes on the island, grew more expansive as mainland Krabi's interactional scenes and images, together with ideas from the outside world beyond Krabi, increasingly attracted their attention and assumed influential roles. Mainland cinemas showing Thai films and Hong Kong-produced Chinese martial arts films became a popular mixed-sex social setting where young people could meet each other and engage in imagining "other lives" and "other worlds" beyond Krabi (Appadurai 1991). On one side of the Prince's Pier on mainland Krabi, an openair food bazaar provided a convenient venue and an inexpensive social interactional context. Every evening, hawkers with push carts sold inexpensive but tasty food and snacks, including Islamic food. Nipa Islanders, young and old, frequented this spot for an evening out on the town.

Theorizing about friendship, Verbrugge (1979), Cumming and Henry (1961), and Rosow (1967) posit that friendships begun in early childhood can continue to develop. They can also change in structure and content during the course of a person's life. Little is known about the Thai Muslim social world, how Thai Muslim friendships are formed, or how they operate in adult years. Likewise, within the Thai Muslim life-world, friendship choice-who is considered a friend to a Thai Muslim - is not known. These were social issues I initially sought to understand while living and researching on Nipa Island.

Exploring the Thai Muslim concept of friendship and friendship roles as they were culturally constructed and lived out on Nipa Island, I was able to uncover the coexistence of two forms of friendship. One form was the friendship alliance that individuals formed for themselves during the course of their social life. I call this type a "self-formed friendship." On Nipa Island, this type of friendship was naturally and socially developed through frequent interactions over the years, from playing together since childhood, attending the same school, living on the same island, and, later on, through interacting with each other in multiple interactional contexts.

Another form of friendship on Nipa Island, called kloe-ship, is unique to Southern Thailand. Kloe-ship is a culturally institutionalized form. Unlike the selfformed friendship and unlike, for example, the Andalusian compadrazgo male-female ritualized friendship in which a compadre is of the opposite sex and selected through a ritualized lot-drawing (Uhl 1985), kloeship as practiced on Nipa Island involves same-sex, mostly same-age pairs formed by others. ${ }^{3}$

\section{Self-formed friendship}

Nipa Islanders have multiple linguistic terms that distinguish various types of friend and the gradients and nuances of friendship.

The term phuean 'friend' connotes a person with whom one interacts in general. Among friends, there are playgroup friends (phuean len) and there are

\footnotetext{
${ }^{3}$ I would like to thank Nipa Laiban for assigning the essay "My Best Friend" to her sixth grade students at my request and for sharing her insider's knowledge about kloeship on Nipa Island.
} 
classmates (phuean rian). The two may overlap in that playgroup friends in the home playground may also become classmates, although not all classmates are playgroup friends. According to my observations, the quality of friendship and the frequency of interactions among the different types of friends vary. Within multiple circles of friends, a selected group of friends eventually became close friends or phuean sanit. Unlike the American pattern, in which friendship gangs tend to be male (Sullivan 1953; Halliman 1979), Nipa Islanders, both male and female, children and adults, had their own groups of close friends or friendship gangs. Within the school context, I was able to decode non-verbal behaviors that were kinesic, behavioral displays of the friendship bond. One display, repeatedly acted out within the school context, was the act of storing personal belongings together. Upon their arrival at school in the morning, close friends would put their briefcases and lunch boxes together in the same location outside the classroom before going out to play together in the open school playground. Before going into the classroom they had to remove their shoes. Again the shoes of a group of close friends were set side by side in the same location. A similar pattern of encoded behavior was repeated on the day the class had its physical education hour, the last class session of the day, when students were asked to clear the classroom before participating in the physical education exercises. Comparisons of the names of the owners of briefcases and shoes on a particular spot invariably matched the names of students in a single playgroup.

From among members of a group of close friends, pairs of best friends, called phuean sanit thisut (closest friend, best friend) or sometimes phuean rak (beloved friend), formed. Best friends were almost always seen in each other's company and doing things together. Applying further Birdwhistell's kinesic research approach of observing body language as a coded communicative behavior (Birdwhistell 1970), I paid close attention to communicative body language that could operate as kinesic clues to the presence of friendship bonds. I noticed female kinesic communication of best friends bonding in their walks around the hamlet holding hands. I witnessed dyadic pairs of best friends, both male and female pairs, walking around the hamlet in warm, interbody contact, one friend wrapping his or her arm around the other friend's neck (see figure 1).

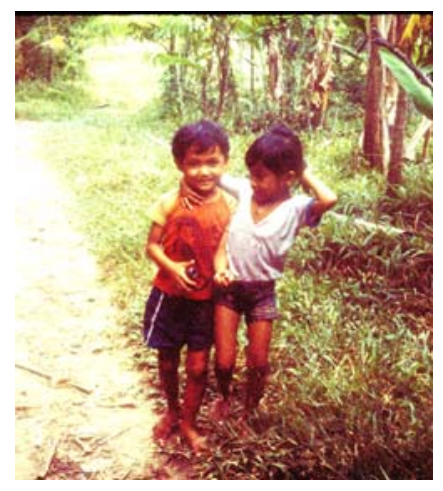

Figure 1: A pair of childhood close friends

When best friends sat together, at home or on the concrete playground, they would lean against each other in tactile communicative closeness. This kinesic expression of close bonding was observable from preschool age on and continued into adulthood, particularly among females, who were less shy about tactile expressions of friendship bonding.

Applying discourse analysis, defined as the analysis of language in use (Brown \& Yule 1983: 1), I implemented a research 
strategy aimed at uncovering the meanings of friendship and the ways in which young Nipa Islanders verbalized about their friends. I was interested to learn which specific behaviors would be singled out by the people themselves as concrete expressions of strong friendship bonds in order to compare these with my observations of kinesic behavior, as discussed above. I requested the cooperation of the sixth grade teacher to ask her students, 25 male and 27 female students, to write an essay entitled "My Best Friend." I selected the sixth graders as the cognitively most mature class in the six-year elementary school on the island on the assumption that they would be more articulate than lower-grade students. Strategically, it was not possible to obtain this form of expressive discourse once the students finished the sixth grade, since, in two years time, most of the males would begin to work as wage-earners on fishing boats, many of them off the island in Phuket.

Content analysis of the written essays identified two qualities female sixth graders valued most in their best friends: loving-kindness and good character. The next set of attributes frequently selected pertains to the nature of their interpersonal relationships. One student portrayed her friendship as follows: "We have been the best of friends since childhood. All through these years, we have never quarreled." This sentiment captures the feelings of many who wrote "I love my best friend dearly. We've always been friends-during happy times as well as through troubled, unhappy times." Thus, friendship is seen as a relationship that has been nourished, tested through time, for better and for worse, and perpetuated through constant material and emotional sharing and understanding which strengthens the bond. Interestingly, as communicated in these essays, Nipa Island female adolescents place a high emphasis on the emotive (Jacobson 1960). This characteristic appears to correspond to what Gilligan (1978) has observed as a gendered tendency of females, i.e., putting a greater emphasis on interpersonal relations.

Male sixth graders articulated their views somewhat differently. While good character was likewise most frequently cited as an attribute of their best friends, the instrumental and the interactional (Brown \& Yule 1983), more than the emotive, were highlighted. For example, males were appreciated as good friends for sharing and rendering assistance to each other, expressed in an essay as "giving help whenever it is needed, without having to be asked for it." Culturally, the latter attribute is linked to the Thai cultural value of mi nam chai; 'to have a heart', 'to be thoughtful' are the closest English glosses, although there is no exact English equivalent.

In addition to the above attributes specifying who is valued as a best friend and what the friendship bonding process involves, many writers, both male and female, expressed admiration for their best friend as "an excellent student" or "a good son" or "a good daughter." It appears that, among Nipa Island sixth graders, friends can serve as significant peer role models. This view imparts an additional constructive dimension to peer interactions and relationships.

The positive end of the friendship continuum includes mit - this marks the point where a good friend becomes a true friend, or phuean thae. A female sixth grader defined mit as "someone who is 
genuine in his/her relationship with me, thinks with me, and acts honestly towards me." Another student wrote, "A mit is someone who is a true friend (phuean thae)."

Of all friends, the ideal is phuean tai, referred to colloquially as phuean si 'friend unto death'. Similar to "friend unto death" relationship in Central Thailand (Piker 1968), this ideal form of friendship requires a total mutual commitment. As conceived on Nipa Island, to become "friends unto death," the friendship has to undergo continual tests of constancy, sharing, giving, and selfsacrifice. As such, "friends unto death"are precious and rare. "Eating friends are easy to find. Friends unto death are hard to come by," is a well-known Thai proverb quoted by a number of essay writers which emphasizes the centrality of the "friend unto death."

At the opposite, negative end of the friendship continuum is the friend called metaphorically phuean kin or 'eating friend'- the fair-weather friend who remains a friend as long as he/she stands to gain by the relationship. Likewise to be shunned as negative role models are phuean chua, or 'bad friends', defined as those who lead one astray, getting one involved in trouble and in negative behaviors like smoking, drinking, stealing, or taking drugs. Other bad friends were identified as those who are insincere in their friendship. One student wrote, "They pretend to be nice to us, but, behind our backs, say bad things about us and backbite us."

\section{The kloe-ship (phuk kloe)}

As a form of social alliance, how does kloe-ship differ structurally from selfformed friendship? And what can a kloe do that a self-formed friend cannot do? In other words, what are the differences in the expectations, ideology, and performance of kloe-ship in real life as compared to self-formed friendships.

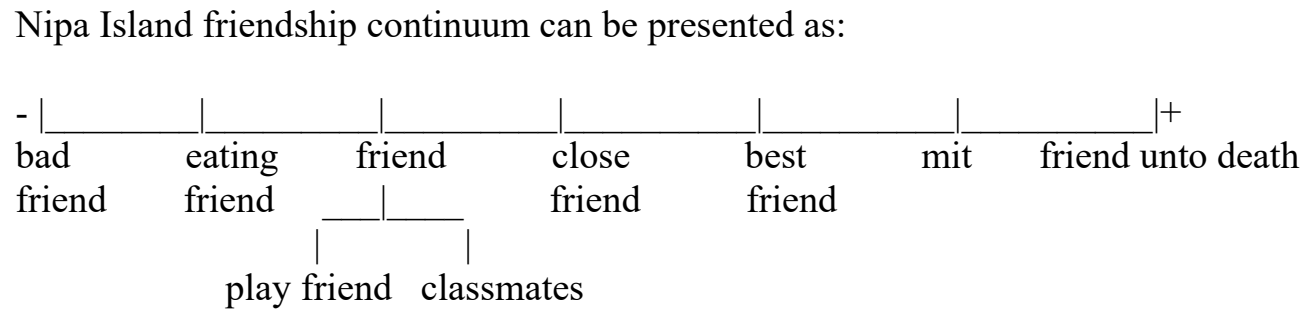

Figure 2: Nipa Island friendship continuum 
Kloe-ship is a unique social form in its structural characteristics, in its formation process, and in the cluster of attitudes subsumed as its ideology. Unlike the selfformed friendship, formed and developed since childhood, kloe-ship on Nipa Island is formed later on and can be formed at any period in life. As mentioned earlier, kloe-ship is formed for the dyadic pair by others. These others can be anyone, though they are usually a parent, a relative, or a friend.

Kloes are of the same sex, tend to be close in age, if not the same age, and can be from the same village or from another location. Structurally, a kloe-ship is characterized by the existence of a commonality that the person who initiates the bonding considers special. The special commonality can consist of being born on the same day and the same year, having similar facial features ("they look alike"), having similar characters, personalities, or mannerisms, e.g., walking the same way, or sharing similar experiences, e.g., eloping to live on Nipa Island on the same day, as was the case for one pair of kloes.

When a kloe-ship is formed for them by a parent, affective and ideational underpinnings are present in some cases. For example, in one case, the mothers of the two girls were best friends themselves. Each had a daughter about the same age. One of the mothers explained that when the kloe-ship was formed for the two girls, she and her friend wished to see their happy friendship bond perpetuated in their daughters' generation. In another case, a father said that, while he was visiting a friend in another province, he grew very fond of that friend's daughter, who happened to be about the same age as his oldest daughter. He proceeded to form the kloe-ship for them. Many kloe-ships have been formed through such warm parental feelings that a parent in one family has had for a child in another family.

As is apparent in many cases, kloe-ship as a social link operates outside the normal friendship framework. It is an extension of the traditional kinship network that exists within the culture. Once a kloe-ship is formed, the parents, siblings, and relatives of the pair of kloes are called by the same kinship terms as his or her counterpart, that is calling his or her kloe's parents Dad and Mom and his or her older siblings, older brother, older sister, and so on, thereby linking the two families in a fictive familial bond. Another distinctive feature of the kloe-ship is that, although it is a dyadic bonding like the self-formed best friend pairing, a person in a kloe-ship bond doesn't need to limit himself or herself to a single kloe. As kloe-ship can be formed at any time in life, more kloes can be added to one's social circle of friends. One Nipa Islander informed me that she had three kloes.

Gender difference in the formation of kloe-ship is marked. While $81 \%$ of the females in my study group had kloes, only $28 \%$ of the males had them.

The analysis of the structure and the process of kloe-ship formation points to a certain metaphysical attention to parallels in the cognition of Nipa Islanders, who appeared to be keen observers of people's physical characteristics and personality traits. I see another impetus for the kloeship formation in the desire of the adult generation to perpetuate, strengthen, and expand the social map (Ardener 1993) of those they cared about. An interesting question is: why did they actualize these concerns and wish more for daughters and female friends than for sons and male 
friends? A reasonable explanation is that parents and other adults on Nipa Island felt that men gained social and spatial mobility fishing occupations in Krabi and beyond Krabi and, thus, had ample opportunities to meet new people and form new friendships themselves. In contrast, Nipa Island women, particularly young girls, who were more cloistered on the island as expected of their gender, had less spatial mobility. They therefore had limited prospects for forging and extending their social networks beyond the home island itself. As parents are generally concerned for the safety and security of their children (LeVine 1974) and as Nipa Island parents wanted to provide opportunities for their daughters to travel and live elsewhere safely without being victimized or violated and to meet more potential spouses, the village, the home, and the family of her blood relatives, as well as those of her kloe, served well as this safe space. At the home of her kloe, she would be provided with the physical and emotional security of substitute parents, her kloe's parents. She could gain access to the social world of her kloe's and of her kloe's family, beyond the social circle that she had already created in her own home village.

Finding one's self, that is, knowing who you are and what you stand for, is a critical development process during adulthood. According to Fine (1981), the formation and development of friendships with someone on a completely different criterion than the self-formed friendship is important for the development of the self. Comparatively, kloe-ship has its distinctive contextual and ideational norms that are entirely different from those of the self-formed friendship. As the kloe is most often not a person one has been familiar with since childhood, the relationship requires the mastery of new social skills that ultimately contribute to a more expansive development of the self. It provides a social context for practicing interpersonal skills that can be applied to future interpersonal encounters.

\section{Tipp and Mali}

In 1983, Tipp was 20 years old.

He felt pretty good about himself. Young, strong, and holding a steady, incomepaying job as a hired hand on a deep-sea fishing trawler in Phuket Province, he was doing well relative to other young fisherman friends from Krabi and Nipa Island. His older brother, a hired hand on a Phuket trawler, had found him a job on the same fishing trawler. To Tipp, Phuket was an exciting place. It was a booming tourist town, the best known on the Andaman coast, with interesting social scenes and places to visit. In Phuket, he saw a greater diversity of people than he had in Krabi: other khon tai (Thai southerners), Bangkok tourists, and many, many Western tourists. And Tipp, with his youthful good looks, was popular among the young girls of Phuket. His fair skin stood out among the very tanned Southern Thai men. Tipp thoroughly enjoyed his popularity and his independence, earning his own money, and living on his own in a small place that he shared with his older brother and two other Krabi fisherman friends and coworkers.

One day Tipp's world, secure and happy, was jolted by a shock.

He met a young girl, Mali, who was as pretty as the flower blossom that was her name. After a few meetings and a few outings together during his off hours from fishing, Tipp found himself very much in 
love with Mali, and, to his delight, she returned his affections. Tipp wanted to marry Mali. He wanted to set up a home with Mali taking care of the house and cooking for him like the wives of his married friends did for them. He dreamt of good home-cooked meals. He looked forward to putting an end to the fast food from food-vending stalls and the inexpertly cooked meals he and his bachelor fisherman friends made.

The big problem was Mali's employer refused to let Mali quit her job. Mali had been working as a hostess in one of the many discotheque bars that catered to Phuket tourists. Her good looks and easy, pleasant smiles made her a popular hostess. She was much sought after for dances. Not wanting to lose a major attraction for his bar, the owner of the bar, a nakleng (a man who wields power over other men and can order other men to do dirty jobs for him), threatened that, if Mali were to leave, she would face unpleasant consequences.

Tipp and Mali were in a quandary.

Tipp's brother and his fisherman friends from his Krabi hometown empathized with him. After several consultations, they evolved a pha $n i$ plan. Pha $n i$ is an elopement strategy, known and practiced throughout Thailand, including on Nipa Island. It is normally a marriage strategy in which a hopeful son-in-law checkmates his girl friend's family's disapproval by spiriting her away secretly from her family. In Tipp's case, it would be a flight from the disapproval and the threat of Mali's boss. The situation turned into a test case for male friendship bonding and male solidarity. In the plan, Tipp's friends and his brother's friends were mobilized to serve as assistants and bodyguards in the pha ni.

The plan succeeded without a hitch. It worked beautifully because the owner of the bar dared not carry out his threat when he realized that he was dealing not only with young Tipp but with the whole group of Krabi fishermen working in Phuket. Despite his nakleng-ness, he dared not force an open confrontation with the group. The Krabi fishermen upheld the inculcated masculine value of luk phuchai 'manhood', defined as being courageous and not shirking away from facing an adversary or from fighting man-to-man when the situation calls for it. Among fishermen working on trawlers in Phuket, the record of previous confrontations had proved Krabi men to be tougher and better fighters than Phuket men.

Tipp took Mali to Nipa Island to live with his older brother's wife, a Nipa Islander by birth. Tipp's selection of Nipa Island as their safe place, a place of refuge, was a perfect choice. Tipp's brother, likewise a fisherman on a Phuket trawler, was absent a great deal of the time on his job. Tipp's sister-in-law, lame in one leg and insecure about living by herself with her two-yearold daughter, was more than happy to give the young couple a refuge. Her ancestral home on Nipa Island was big enough to accommodate two families.

Mali gave her sister-in-law the muchneeded companionship and was, as a good sister-in-law, very conscientious about helping with the housework and with taking care of her sister-in-law's toddler daughter. From then on, Tipp and his brother left home for their jobs in Phuket with the secure feeling that their wives had each other for company and assistance. Unlike Tipp's bachelor days when the 
attractions of the big city kept him mostly in Phuket, the two brothers now came home to Krabi together during the off period and felt closer as siblings.

\section{Dara}

In the case of Dara's elopement, described at the beginning of this article, close friends (phuean sanit) of both parties played significant roles in the organization of the elopement and in the maintenance of secrecy. Not even Dara's older sister got wind of the planned elopement. She was carefully kept out of the loop. It was feared that, given her responsibilities as the older sister, she might inform on her younger sister. This elopement, which was the couple's last resort for forcing Dara's parents to accept their marital choice, likewise succeeded. A friend of Dara's boyfriend gave them shelter in another village and persuaded the to-imam of his village to legitimize the marriage in an Islamic religious ritual. After about a month away, through another friend, the newlyweds sent a message to Dara's parents that they were properly married and that they would like to kho khama 'request forgiveness' for the elopement. The couple returned to live in Dara's parents' house on Nipa Island after performing the kho khama ritual. While elopement is the cultural mechanism for solving a parent-daughter conflict over marital choice, the kho khama ritual functions as the societal mechanism through which the young couple is reincorporated back into the family and the community. The acceptance of the young couple back into the family was further signaled by the action of Dara's parents: giving their own bedroom in the main house to the young couple. The parents moved to a new bedroom, a small, modest space partitioned off from the bamboo-and-thatch kitchen house at the back of the main house.

In other boy-meet-girl scenarios, friendship among men can lead to opportunities for young men to meet more prospective brides. As marriages on Nipa Island ceased being arranged by parents, a young fisherman would sometimes go with his friend to visit the latter's village during their off period, which came twice a month during the time of full moon. There he might meet a young girl he liked. His friend's goodwill was critical, if he desired to court or eventually marry her. That friend could become the strongest gobetween and supporter of his love interest.

\section{Multiplexity of friendship}

Theorizing friendship as it traverses diverse interactional contexts, Verbrugge (1979) advances the concept of "multiplexity of friendship," which she develops from Gluckman's concept of "multiplexity of the social network." Multiplexity of friendship, in Gluckman's terms, refers to "the co-existence of different normative elements in a social relationship" (Gluckman 1962). Verbrugge labels a friendship "multiplex" if two people share two or more concurrent bonds, e.g., kin, neighbors, or co-workers. Verbrugge's theoretical framework assists in clarifying the multilayered social networks that are embedded in the friendship bonds on Nipa Island.

Tipp's case, cited above, exemplifies the viability of "co-worker friends" (phuean ruam ngan), as well as sibling bonding. Male Nipa Islanders had their best friend or close friend who could later on in life become their patron (Hanks 1962; Wijeyewardene 1967), someone who could assist them in locating a job opening 
on a fishing trawler, and thereby become a co-worker friend. Additionally, some coworkers whom they met on the job could eventually become new friends. Female Nipa Islanders likewise exhibited the friend-to-co-worker pattern in the logistic support given in the all-women riceplanting and rice-harvesting seasons and at family rituals and family celebrations on the basis of friendship (Anderson 1986).

Similarly, the second type of multiplexity, which Verbrugge calls "kinfriends," is not gender-specific. Grouped within this type are those who are kin as well as friends. In a small community, especially on an island community like Nipa Island, this type was widely distributed, particularly among cousins and relatives who were close in age or were in the same class at school. It did not include siblings, however, for, although siblings might develop a close rapport with each other, play together all the time, and feel like friends to each other, the formalized sibling terms of address governing relative age and the normative cultural expectations of siblings gave a different nuance to their relationships, outside the group labeled friend. First and foremost, they were siblings. This was the reason, for example, why the older sister of the eloping girl in the second case study cited above was not consulted or taken into the circle of confidants when her younger sister eloped.

Verbrugge's third type of friends is "neighbor friends." Within Nipa Island's friendship context, this appeared during the children's younger years in the home playground where boys and girls living in houses adjacent to each other interacted in play and in other social occasions. They might continue to interact in this way when they found themselves in the same work setting during adolescence and adulthood.

In fishing trawlers and in the paddy field work settings, the relationship between many dyadic pairs was found to be of a fourth type, comprised of three-folded affiliations that deepened the bonding. They started as kin and friends and then later also became co-workers.

A number of them nourished relationships of a fifth type, comprising concurrent affiliations as kin, friends, neighbors, and co-workers.

Nipa Island friendship patterns contrast interestingly with Verbrugge's findings from Detroit, U.S.A., and from a city in West Germany. Within Verbrugge's American and German urban contexts, there was a bias against highly multiplex types of friendship with several affiliations. It was felt that the more complex a tie was, the less easily they could withdraw from contact with each other. Her findings suggest that in those two Western cultural settings there was a reticence towards forming tight-knit friendships, perhaps due to the high priority attached to the sense of personal independence.

Nipa Island friendship patterns, on the other hand, encourage and foster high levels of multiplexity. Why is there this difference? On Nipa Island, ethnicity acts as a strong determinant. Like the SinoThai ethnic group throughout Thailand, for whom group cohesion and cooperation are so important for their social and economic survival that they are actively cultivated and mobilized (Veda 2001; Wongsuphap 2005), Nipa Islanders as ethnic Thai Muslims need to foster this social capital of interpersonal, ethnic networks in order 
to create a wider power network through which the group can negotiate and act effectively. For example, in 1983 in the trawler fishing occupation, the fact that the captains of two fishing trawlers (one in Krabi and the other in Phuket) were Nipa Island men was quite expedient. The captain had the authority given to him by the boat owner to select his own fishing crew, a group that would both work well with him and work together. Young men from Nipa Island seeking this type of wage-earning occupation certainly had an "in" with both fishing trawler captains.

In Central Thailand, friends, and especially close friends, call each other's parents, siblings, and relatives by the same kinship terms used by the friend. This was, however, not the case among Nipa Islanders. The older villagers that Nipa Islanders had known since childhood, parents and relatives of their friends as well as others, already had quasi-kin terms, age defined, attached to them. Young Nipa Islanders had been taught to respect their elders and to call them bang/cha 'older brother/sister' or, if they were significantly older, ne 'grandmother/grandfather'. The norm of using quasi-kin terms appeared on Nipa Island instead within the kloe-ship construct. Comparatively then, Nipa Island kloe-ship provides a mechanism for creating another network of fictive kin in a form comparable to the self-formed friendships of Central Thailand, which would otherwise be lacking in the Nipa Island kinship construct. Also, the fact that the kloe-ship can be formed between Muslims and Buddhists allows for the creation of close bonds that transcend spatial, ethnic, and religious boundaries.

The analysis of kloe-ship on Nipa Island is a first step towards an understanding of this type of social bonding that exists along the Andaman coast among Thai Muslims and Buddhist Thais alike. On the opposite coast, Dejtongkham (2003) has identified the existence of a kloe-ship-like bond called phuk yot. He has found that, within the interactional contexts of Nakhon Si Thammarat, Songkla, and Pattalung, this institutionalized form of friendship is pivotal socially as well as occupationally. It is constantly invoked during the course of a person's life to smooth the way and expedite matters. One of Dejtongkham's informants has as many as six kloes. Khu kloe, or the kloe pair, on the southeastern coast likewise call each other's kin by the kinship terms and falling in love with one's kloe's siblings is to be avoided since such marital unions are disapproved of in the same way as a marriage between close relatives (Pongpaiboon 1994).

It is not known how long kloe-ship has existed as a social institution. No doubt, the existence of both the self-formed friendship and kloe-ship on Nipa Island has expanded social ties. And for young Nipa Islanders concerned at this period in their life with forming cross-sex relationships, learning how to interact with other members of society, and making their start in life as an adult, kloe-ship certainly made their social world grow larger, more varied, and richer through the accompanying extended social networks. Friendship in the social setting of Nipa Island, an island community, hence, has far-reaching implications and meanings beyond the one-on-one relationship between the dyadic pair. The fact that diverse forms of friendship exist marked by ten distinct linguistic terms for different types of friends underlines the importance that Nipa Islanders place on friendship. 


\section{Confidant, comrade, and co- worker}

For Nipa Islanders, close-friend and bestfriend bonds formed and sustained during early childhood and the school years generally continue beyond those periods. During adolescence and adulthood, it was the best friend, rather than parents or siblings, who becomes an individual's confidant. They confide in their best friend about their suitors, about their boyfriends or girlfriends, and, once they are married, about marital difficulties they might not want to share with their birth family for fear of worrying them-in other words, most of the hopes, happiness, and conflicts that stem from cross-sex relationships.

In the work context, friendship alliances are just as meaningful. During the annual rice-planting and-harvesting seasons, when women work their hardest to fill their granaries with sufficient rice to feed the family for the whole year, one's best friends, one's group of close friends, and female relatives are the people one can count on for assistance, forming an allfemale workgroup. This group mobilizes as a cooperative work force in the rice paddies. At rituals such as weddings, similar support is again in evidence. The cooperative response given by others on such occasions signals one's social standing within the family that is how well liked they are in the eyes of others. At one wedding in which I participated, the bride's best friend and close friends arrived at the bride's home the day before the wedding to help with the needed preparations and the cooking. They stayed overnight at the bride's home, even though their own homes on the island were close by. On the wedding day, they helped to serve food to the guests, did the dishes (see figure 3), and then stayed on to help with the clean-up after all of the other guests had departed.

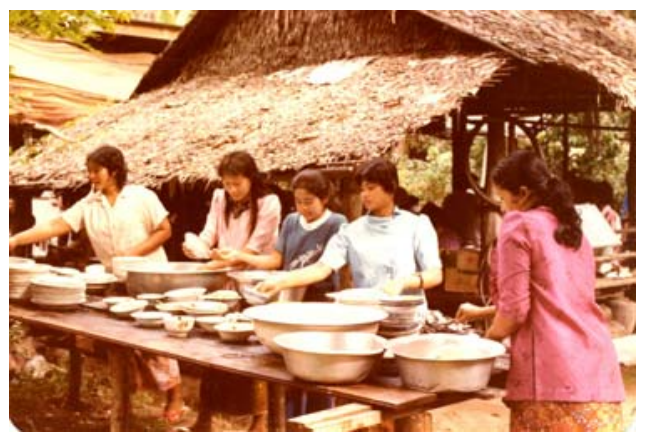

Figure 3: Close friends assisting in a wedding feast

While female friendship bonds in 19821983 tended to be confined to those friends on the island, Nipa Island's male friendship networks were more expansive. As their access to the outside world increased with their occupation as hired hands on trawlers, either in Krabi or in Phuket, another province 168 kilometers away, their friendship circles expanded to include other fishermen, co-workers on the same or other trawlers, and other friends they encountered in the provinces where they worked. Economic pursuits outside the island are thus a strong predictor of the nature and types of new friendships formed by men and correlate directly with greater opportunities for men to develop new contacts and also new patrons.

Despite new friendships, old friendships formed since childhood with fellow Thai Muslim Nipa Islanders remain strong. Most Nipa Island men with limited education view their occupational prospectives as government officials as limited. Some cite their marginalized status as ethnics as a deterrent. Others say 
they lack "a friend in high places," meaning an influential person who could be his supporter in the patron-client relationship, a Thai relationship pattern beyond the kinship support network (Hanks 1962). For them, Thai Muslim friends on the island, fellow villagers, and former play friends serve as their principal occupational network and contacts. My interviews of working male hired hands on fishing trawlers indicate that the jobs acquired came through their childhood friendship network as much as they came through their kin network. Once they were on the job, friendship alliances among those coming from the same province or from the same village remained strong and could be invoked and mobilized in time of need, as in Tipp's case.

Other young men from Nipa Island generally marry with less fanfare than Tipp to girls whose jobs after matriculating the elementary school tend to be in the domestic domains of helping their mother with the housework, taking care of younger siblings, helping in family stores, vending snacks, and/or working in the rice paddies. The particularity of the emotional and instrumental support given to Tipp and Mali by Tipp's fisherman friends and by his brother's friends became a site where Nipa Island friendship and home village support networks were tested. Tipp's fisherman friends from Krabi gave Tipp the support he needed. The shared experience became laden with meaning. It intrinsically engendered a mutually understood social contract. Tipp was expected to reciprocate in his turn when another friend required support, even if it might be of a different sort.
The recent introduction of reformist Islam to Nipa Island and the wearing of headscarves among a portion of female students and other women in the last five years (Anderson, in press) give added weight to the desirability of kloe-ship formation, a safe social field for young Muslim girls and women who are to be protected from the eyes of male outsiders. In 2008, government-sponsored advanced education in the secondary school in mainland Krabi is available to the new generation of Nipa Island primary school graduates. But very few male graduates take advantage of the opportunity. They prefer the quicker route of becoming wage-earners a few years after finishing sixth grade in order to start saving for their future marriage. Working as hired hands on ocean fishing trawlers is still the primary occupation of most young men, and kin and friends continue to smooth the way for them with the needed connections and entry-level jobs on fishing trawlers.

For Nipa Islanders, friendship is a significant relationship because it can develop into meaningful lifelong social and economic connections and vital support networks, within the island as well as across groups to others outside the island. It changes the otherness of the "they" into the bonded "we." For ethnic minorities like Nipa Islanders, being without a friend is like sailing onto the open sea without a lifeboat. It is social suicide.

\section{References}

Anderson, Wanni W. 1986. Thai Muslim Adolescents' Self, Sexuality, and Autonomy. Ethos 14 (4): 368-394.

---. 1988. The Social World and Play Life of Thai Muslim Adolescents. Asian 
Folklore Studies 47: 1-17. In Thai, Sangkom Wairun Thai Muslim Kap Wattanatham Kanlen. In Warasan Sankomwittaya Lae Manutwittaya 1(5): 26-44.

---. in press. Mapping Thai Muslims: The Andaman Coast. To be published by Silkworm Books, Chiang Mai, Thailand.

Appadurai, Arjun. 1991. Global Ethnoscapes: Notes and Queries for a Transnational Anthropology. In Recapturing Anthropology: Working in the Present, edited by Richard G. Fox, pp.191-210. Santa Fe, NM: School of American Research.

Ardener, Shirley, ed. 1993. Women and Space: Ground Rules and Social Maps. Oxford: Berg.

Aroonmanakun, Wirote. 2004. Thai Romanization 1.25 (software). Bangkok: Chulalongkorn University.

Birdwhistell, Ray L. 1970. Kinesics and Context: Essays on Body Motion Communication. Philadelphia: University of Pennsylvania Press.

Brown, Gillian, and George Yule. 1983. Discourse Analysis. Cambridge, Eng.: Cambridge University Press.

Cumming, E., and W. E. Henry. 1961. Growing Old: The Process of Disengagement. New York: Basic Books.

Dejtongkham, Akom. 2003. Puk yod [Forming Kloe-ship]. Nakhon Si Thammarat, Thailand: Ratchapat Institute.

Fine, Garry Alan. 1981. Friends,
Impression Management, and Preadolescent Behavior. In Development of Children's Friendships, edited by Steven R. Asher \& John M. Gottman, pp. 29-52. Cambridge: Cambridge University Press.

Gilligan, Carol. 1978. In a Different Voice: Women's Conviction of the Self and of Morality. Harvard Educational Review 47(4): 481-517.

Gluckman, Max 1962. Les Rites de Passage. Essays on the Ritual of Social Relations, edited by Max Gluckman, pp. 1-52. Manchester: Manchester University Press.

Halliman, Maureen. 1979. Structural Effects on Children's Friendships and Cliques. Social Psychology 42: 43-54.

Hanks Jr., Lucien M. 1962. Merit and Power in Thai Social Order. American Anthropologist 64(6): 1247-1261.

Levine, Robert A. 1974. Parental Goals: A Cross-cultural Review. Teachers College Record 76: 226-239.

Piker, Steven. 1968. Friendship to the Death in Rural Thai Society. Human Organization 27(3): 200-204.

Pongpaiboon, Suthiwong, ed. 1994. Potchananukrom Paktai [Encyclopedia of Southern Thailand]. Songkhla, Thailand: Institute of Southern Thai Studies, Srinakharinwirot University.

Rosow, I. 1967. Social Integration of the Aged. New York: Free Press.

Sullivan, Harry Stack. 1953. Interpersonal Theory of Psychiatry. New York: Norton \& Company. 
Uhl, Sarah C. 1985. Special Friend: The Organization of Intersex Friendship in Escalona (Andalusia), Spain.

Anthropology ix: 129-152.

Veda, Yoko. 2001. Sino-Thai

Entrepreneurs and the Provincial

Economies in Thailand. In Alternate

Identities: The Chinese in Contemporary

Thailand, edited by Tong Chee Kiong

And Chan Kwok Bun, pp. 169-188.

Singapore: Times Academic Press.

Verbrugge, Lois M. 1979. Multiplexity in Adult Friendship. Social Forces 57(4): 1286-1309.

Wijeyewardene, Gehan 1967. Some Aspects of Rural Life in Thailand. In Thailand: Social and Economic Studies in Development, edited by T.

H. Silcock, pp.65-83. Canberra:

Australian National University Press.

Wongsuphap, Suleemarn N. 2005. The Social Network Construction of the Baba Chinese in Phuket. In Dynamic Diversity in Southern Thailand, edited by Wattana Sagunnasil, pp. 275-298. Chiang Mai: Silkworm. 